\title{
Does the Oil Price Influence the Exchange Rates in Nigeria? Empirical Evidence from Wavelet and Causality Approaches
}

\author{
Tomiwa Sunday Adebayo
}

Cyprus International University, Nicosia Mersin 10- Turkey, Faculty of Economic and Administrative Science, Department of Business Administration, Turkey.

Email.twaikline@gmail.com Tel. +905338440168

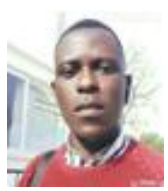

\begin{abstract}
This study explores the connection between the exchange rate and oil price within the framework of time and frequency utilizing monthly data between January 2007 and March 2020. The study deployed the wavelet tools to investigate this relationship. Furthermore, Granger and Toda Yamamoto causality tests were employed as a robustness check for the wavelet coherence techniques. Findings from the wavelet power spectrum shows; (a) a significant vulnerability in the exchange rate between 2014M6 and 201412, between 2017M1 and 2017M12 2016M1; and (b) a significant vulnerability was found in oil price between 2008M1 and 2008M12, between 2014M1 and 2014M12. The wavelet coherence technique reveals; (a) negative co-movement between the exchange rate and oil price between 2009M10 and 2011M3, between 2012M1 and 2012M3, between 2014M2, 2015M6 and between 2019M2 and 2019M11. The Granger and Toda Yamamoto causality tests reveal a bidirectional interaction between oil price and exchange rate. The variance decomposition shows that as the months dwindle, $40.2 \%$ and $40.5 \%$ of discrepancy in the exchange rate can be explained by oil price in the twenty-third and twenty-fourth month respectively. This signifies that oil price is a good predictor of the exchange rate in the long term. Also, the variance decomposition and causality tests provide a piece of supportive evidence for the wavelet coherence technique. Key recommendations are suggested based on these findings.
\end{abstract}

Keywords: Exchange rate, Oil price, Wavelet tools, Granger causality, Toda Yamamoto causality, Variance decomposition. JEL Classification: G15; Q43.

Citation | Tomiwa Sunday Adebayo (2020). Does the Oil Price Influence the Exchange Rates in Nigeria? Empirical Evidence from Wavelet and Causality Approaches. Asian Journal of Economics and Empirical Research, 7(2): 126-135. History:

Received: 13 March 2020

Revised: 17 April 2020

Accepted: 19 May 2020

Published: 10 June 2020

Licensed: This work is licensed under a Creative Commons

Attribution 3.0 License $(\mathrm{cc})$ Er

Publisher: Asian Online Journal Publishing Group
Funding: This study received no specific financial support.

Competing Interests: The author declares that there are no conflicts of interests regarding the publication of this paper.

Transparency: The author confirms that the manuscript is an honest, Transparency: The author confirms that the manuscript is an honest,
accurate, and transparent account of the study was reported; that no vital accurate, and transparent account of the study was reported; that no vital
features of the study have been omitted; and that any discrepancies from the features of the study have been omitted
study as planned have been explained.

Ethical: This study follows all ethical practices during writing.

\section{Contents}

1. Introduction

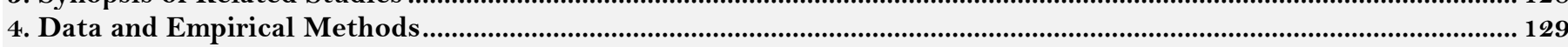

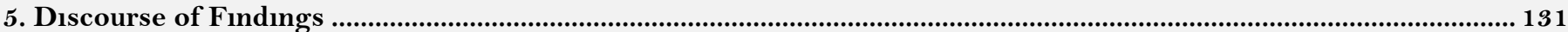

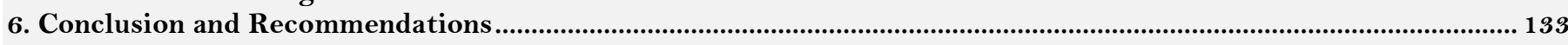

References... 


\section{Contribution of this paper to the literature}

This study is unique from previous studies because; (a) it deployed the wavelet approach (wavelet power spectrum and wavelet coherence techniques) which is a technique established in physics and engineering but new in finance and economics to explore the link between oil price and exchange rate compared to the previous studies that utilized frontier analysis; (b) it examines the co-movement between oil price and exchange rate by utilizing monthly data which produces more comprehensive facts about the two variables; (c) the Granger and Toda Yamamoto causality tests were deployed to provide supportive evidence for the wavelet coherence technique.

\section{Introduction}

The core reason the central bank is established is the maintenance of external reserves in safeguarding the international value of the domestic currency. Due to fluctuations in macroeconomic indicators like exchange rate, the objective of the central bank is getting more diff to achieve. This is because fluctuation in oil prices affects the exchange rate of oil-exporting economies like Nigeria. Before 1986, the Nigerian government pegged the Naira to the British pound sterling and soon after moving to the US dollar between 1970 and 1985 , the exchange rate dropped below one naira to one dollar, whereas the oil price yearly average price fluctuated. Pre-1986 data on oil prices and exchange rates showed that the exchange rate was reasonably constant compared to the price of crude oil. Here are countless facts, notably in the post-Breton woods period, indicating the significant role of oil price volatility in shaping the direction of the exchange rate (Adeniyi, Omisakin, Olusegun, Yaqub, \& Oyinlola, 2012).

As Krugman (1983) stated, the rise in exchange rate is due to increase in oil prices and loses value in reaction to declining oil prices in oil-exporting economies, whereas in oil-importing economies the reverse is anticipated to represent the situation. A volatile exchange rate renders foreign trade and investment quite challenging, as it heightens the risk of exchange rates (Yang, Yang, Ho, \& Hamori, 2019). The volatility of exchange rates appears to increase the risk and uncertainty of international transactions and pushes a nation to exchange-rate risks (Olayungbo, 2019). Economists are routinely reported to have observed a significant decrease in foreign oil prices during the global economic crisis in 2008. This led to a drop in oil income and undesirable fluctuations in the exchange rates for main oil-exporting countries, particularly those not too well-diversified. In certain OPEC countries, the condition was unfavorable with low rates of cumulative foreign reserves.

The inspiration for this study is derived from the investigator's observation that the collapse in oil prices witnessed towards the end of 2014 impacted the USD/Naira exchange rate. The level at which the Naira was devalued repeatedly between September 2014 and June 2015 by the monetary authorities. This is because it was no longer feasible to continue defending the local currency utilizing the foreign reserves of the country. Furthermore, the uncertainty of exchange rates caused by adverse fluctuations in oil prices not only translates to growing businesses and foreign exchange risk but also contributes to higher living costs when a country is reliant on imports. To the understanding of the author, no prior studies have explored this interaction deploying the wavelet tools to investigate Nigeria. The structure of the paper is as follows. The theoretical is examined in the second segment. The synopsis of the studies is considered in the third segment. The fourth segment discusses the description of data deployed and empirical methods. The discussion of findings is discussed in the fifth segment and conclusion and policy direction is finalized in the sixth segment.

\section{Theoretical Framework}

The interaction between the oil price and exchange rate can be expounded by utilizing the law of one. The oil price is frequently quoted in $\$$ US by aligning with homogeneity agreement and foreign trade. Thus, the equation 1 below depicts the oil price premised on a foreign exchange.

$$
P^{*}=e+p
$$

In equation 1 above, the oil price logarithm of foreign currency is depicted by $\mathrm{P}^{*}$, is the oil price logarithm in $\$ \mathrm{US}$, and is the logarithm of the $\$ \mathrm{US}$ exchange rate in nominal terms. To comprehend the previous equation, assume there is a fall in $\$ \mathrm{US}$ (i.e. depreciation in $\$ \mathrm{US}$ ), there will be a reduction in the price of oil due to this decrease for foreigner's comparative to the price of foreign currencies for commodities. Therefore, international consumers buying power and demand for oil are growing in reaction to the growing price of oil in $\$$ US. In terms of arbitrage viewpoint, Equation 1 means that the price of oil in $\$$ US rises as $\$$ US value declines when the oil price in international currencies declines. In other words, verification of the influence of oil price on the $\$$ US exchange rate (Yang et al., 2019).

For example, the oil price increase can lead to wealth distribution differently because of the current account surplus for oil-exporting economies will increase whereas the oil-importing economies current account deficit will increase (Golub, 1983). This study presumes inelastic oil price, thus a boost in oil price leads to a rise in oil expenditure and the US dollar value. Krugman (1983) considered the speculation factor by stating that the influence of oil price on exchange rate could vary based on the gain derived from oil price movement on importers and exporters balance of payment. Though when oil price increase, the value of $\$$ US depreciates in the short-run which lead to long term increase in the value of $\$ \mathrm{US}$. The price of good to describe the influence exchange rate has on the oil price is illustrated in Equation 1. Assuming traded and nontraded goods are part of the general price of the good, it can be separated into the nontraded and corresponding traded price of goods. If the log-linear is taken which is an estimation of the domestic and foreign nations, the specification of consumer price indexes can be portrayed below as;

$$
\begin{aligned}
& P=(1-\psi) p^{T}+\psi p^{N} \\
& P^{*}=\left(1-\psi^{*}\right) p^{T}+\psi^{*} p^{N *}
\end{aligned}
$$

In Equations 2 and 3 above, the prices of traded and non-traded goods for the home and foreign nation is represented by $P^{T} P^{T *}$ and $P^{N} P^{N *}$ respectively, and $\psi\left(\psi^{*}\right)$ the expenditure share weight of nontraded goods in the 
home and foreign nation is denoted by $P^{T} P^{T *}$ and $P^{N} P^{N *}$ respectively. The nominal exchange rate is generated by merging Equations 2 and 3 to form Equation 4.

$$
\left.e=\left(P^{N *}-P^{N}\right)+\left(1-\psi^{*}\right) P^{T *}-P^{N *}\right)-(1-\psi)\left(P^{T}-P^{N}\right)
$$

If the weights of expenditure share of goods that are not traded $(\psi \approx \psi)$ of home and foreign nation are the same, the cost-push impact on goods that are untraded from the oil price fluctuations is related in the home and foreign nations. The home country price of comparative traded goods correlates with the foreign price of traded goods. Hence, if the home nation is the oil importing state, when oil price increases, the prices of relative goods traded in the home country will be greater than that of the foreign nation. Inevitably, there is depreciation in home nation currency. Likewise, assuming the oil-exporting nation is the home nation, there will be appreciation in the home currency if oil price increases. Furthermore, if the monetary factors are incorporated into the exchange rate model, different models can be built to reflect the impact of the price of oil on exchange rates. Let's presume the nominal demand to be $\mathrm{m}\left(\mathrm{m}^{*}\right)$ in the home(foreign) nation, the demand for money which is nominal in the home or foreign nation relying on the extent of price $\mathrm{p}\left(\mathrm{p}^{*}\right), \mathrm{y}\left(\mathrm{y}^{*}\right)$ mirrors the real income, and $\mathrm{i}$ (i*) illustrates interest rate. Assuming the impact from these three indicators on demand of money is alike for the home and the foreign nation, premised on interest rate parity condition, Equation 5 is reconstructed to depict the nominal exchange rate.

$$
e=\left(m^{*}-m\right)+\left(y-y^{*}\right)
$$

According to Lizardo and Mollick (2010) Oil price is accommodated in equation 5 as a supplementary exogenous variable in explaining the impact of the exchange rate. The exchange rate can be determined by considering this long term monetary model.

\section{Synopsis of Related Studies}

The link between the exchange rate and the oil price has been investigated by existing literatures. Amano and Van Norden (1998) examined the link between the exchange rate and oil price utilizing cointegration technique and found that shocks in oil prices can explain exchange rate. Camarero and Tamarit (2002) investigated the interaction between real exchange rate and oil price utilizing cointegration techniques. Finding through the panel cointegration techniques reveal that the real exchange rate is ascertained by oil price in the Spanish peseta. Chen and Chen (2007) examined the link between oil price and exchange rate in G7 economies deploying monthly panel data. The authors observed that oil price can forecast the exchange rate in the G7 economies. Aliyu (2009) deployed quarterly data between 1986 and 2007 to investigate the influence of exchange rate and oil price on the economic growth of Nigeria. The investigator utilized Johannsen cointegration, VECM and pairwise Granger causality test to ascertain this interaction. The Johannsen cointegration revealed cointegration in the long-run and the VECM revealed that both exchange rate and oil price impact economic growth positively in Nigeria. Furthermore, Granger causality depicts one-way causality from exchange rate to GDP growth while a feedback causality was found between oil price and economic growth.

The study on OPEC countries conducted by Korhonen and Juurikkala (2009) revealed a negative and significant interaction between exchange rate and oil price. In the same line, the interaction between the exchange rate and oil price was explored by Zalduendo (2006) and the finding reveals a negative interconnection between oil price and exchange rate in both Venezuela and Algeria. The dynamic interaction between oil price and exchange rate was explored in India by Ghosh (2011) utilizing daily data between 2007 and 2008. The GARCH and EGARCH models were employed to determine this interaction. Findings from the study shows negative interaction between oil price and exchange rate. This shows that increase in the price of oil leads to currency depreciation in India. Furthermore, oil price shock influenced exchange rate permanently. Using 5 ASEAN economies, cointegration test, variance decomposition and the VECM techniques, Basnet and Upadhyaya (2015) investigated the influence of oil price shock on exchange rate, inflation and exchange rate. The investigators observed that oil price does not impact the selected macroeconomic variables in the long-run. However, in the Philippines, Thailand, Malaysia and Singapore, there is a significant response to fluctuation in oil prices.

Utilizing the time-varying autoregressive based model some studies explore the interaction between exchange rate and oil price. Compelling evidence of negative and statistically significant interaction was found between oil price and exchange rate by deploying GARCH model (Cifarelli \& Paladino, 2010; Turhan, Sensoy, \& Hacihasanoglu, 2014). In Nigeria, the impact of oil price shocks on the macroeconomics was investigated by Iwayemi and Fowowe (2011) utilizing Granger causality test, variance decomposition and impulse response. The study indicates no significant interaction between oil price shock and the macroeconomic variables. The causality tests reveal that oil price shock do not cause real GDP, exchange rate, inflation and government expenditure. However, negative oil shock cause exchange rate and real GDP significantly. Employing the wavelet decomposition approach, Reboredo and Rivera-Castro (2013) investigated the nexus between exchange rate and oil price. Using a different time, it was observed that during the pre-crisis period, both oil prices and exchange rates do not depend on each other. However, in the global financial crisis period, oil prices cause exchange rate.

The interaction between oil price and exchange rate was analyzed by Huang, An, and Lucey (2020) utilizing monthly data between 2000 and 2018. The granger causality reveals feedback causality between oil price and exchange rate and a co-movement was found between oil price and exchange rate. Yang, Cai, and Hamori (2017) investigate the interaction between the exchange rate and oil price utilizing the wavelet tools and finding shows an adverse co-movement between oil price and exchange rate for nations that import oil while insignificant comovement was found between oil price and exchange rate for the oil-importing countries. The influence oil price volatility has on exchange rates in Sub-Saharan African economies was investigated by Baek and Kim (2020) by deploying a nonlinear ARDL approach. Finding from this study revealed that in the long run, there is strong and significant interaction between oil price and exchange rate in sub-Sahara Africa economies. However, no significant interaction was observed in the short run. Using Nigeria as a case study and deploying seasonal adjusted quarterly data between 1984 and 2018, (Olayungbo, 2019) examined the interconnection amongst oil price, trade balance and exchange rate. The Johannsen cointegration test reveals cointegration the long-run while the Granger causality test provides evidence for unidirectional causality running from oil price to foreign reserve in the short term but no evidence of causality between exchange rate and oil price. 


\section{Data and Empirical Methods}

\subsection{Data Description}

In this empirical analysis, the variables utilized are oil price (OP) and exchange rate (EXCHR). The variables comprise of monthly data between January 2007 and March 2020 with 159 observations. The data used in this study (oil price and exchange rate) are gathered from the Central Bank of Nigeria (2020) (CBN) and database of the Organization of Petroleum Exporting Countries (OPEC). Figure 1 and Figure 2 depicts the trend in exchange rate and oil price between 2007M1 and 2020M3.

\section{Exchange Rate}

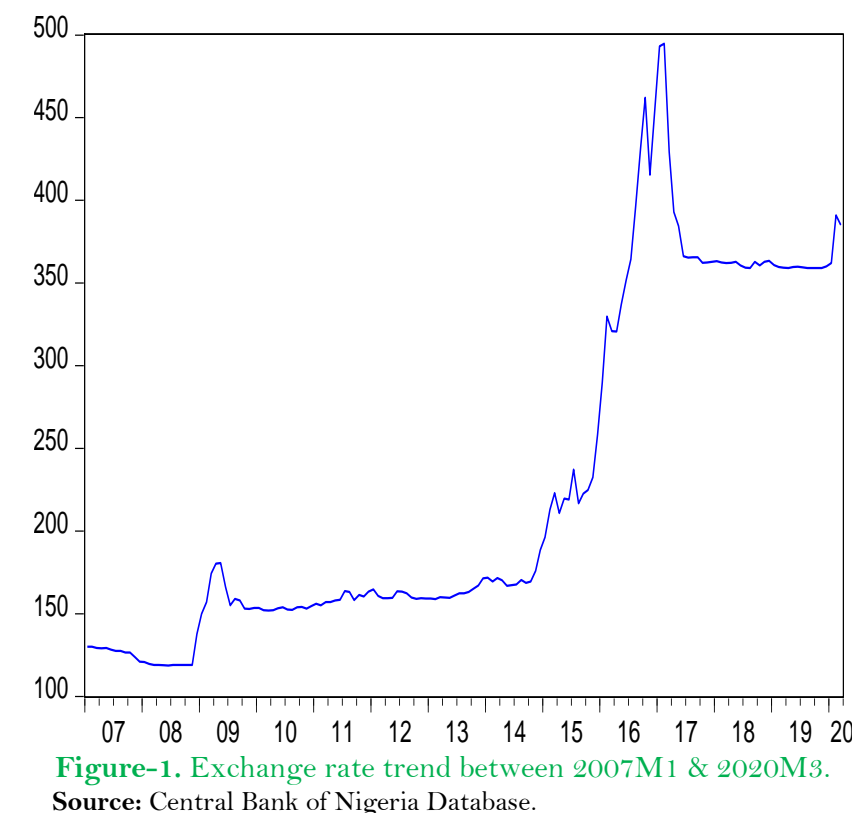

Oil Price

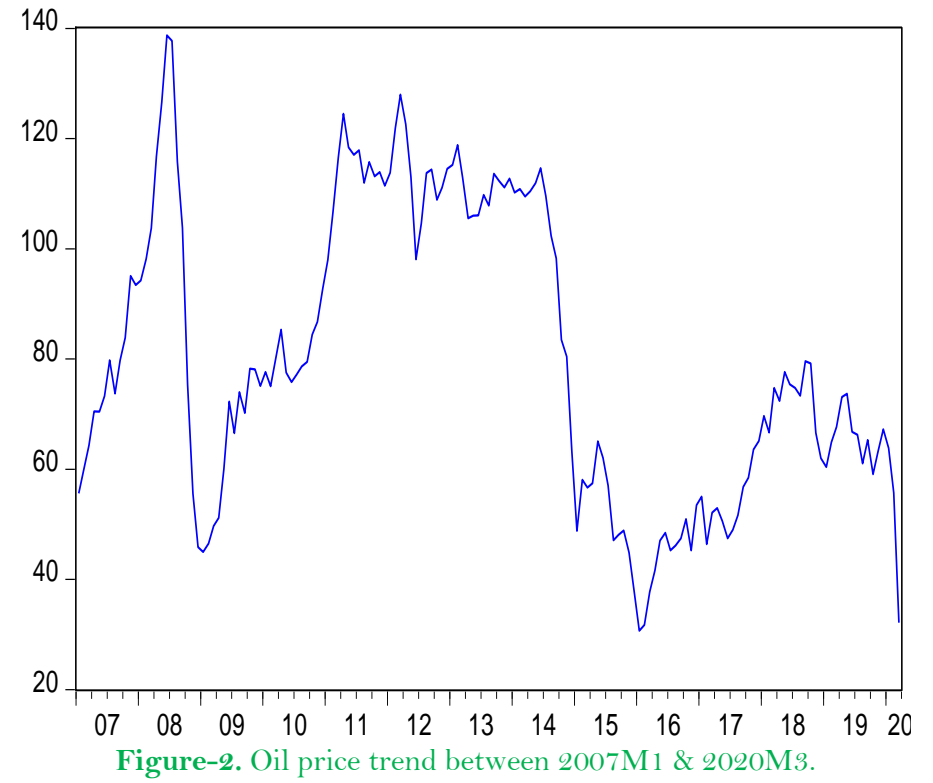

Source: OPEC Database.

Table-1. Descriptive statistics

\begin{tabular}{c|c|c}
\hline Descriptive Stat & Oil Price & Exchange rate \\
\hline Source & WTI & CBN \\
\hline Duration & 2007M1-2020M3 & 2007M1-2020M3 \\
\hline Sign & OP & EXCHR \\
\hline Mean & 80.09126 & 166.8500 \\
\hline Median & 75.11000 & 494.7000 \\
\hline Maximum & 138.7400 & 118.7000 \\
\hline Minimum & 30.66000 & 104.6235 \\
\hline Std. Dev. & 26.56215 & 0.781869 \\
\hline Skewness & 0.221843 & 2.079136 \\
\hline Kurtosis & 1.865943 & 21.81791 \\
\hline Jarque-Bera & 9.824502 & 0.000018 \\
\hline Probability & 0.007356 & 36289.41 \\
\hline Sum & 12734.51 & 1729480. \\
\hline Sum Sq. Dev. & 111476.6 & 159 \\
\hline Observations & 159 & -0.6085 \\
\hline \multicolumn{2}{c}{}
\end{tabular}


Table 1 provide a brief description of oil price and exchange rate. The range of oil price is from 30 to 138 , and from 118 to 498 for exchange rate. The means are 80 and 228 for oil price and exchange rate respectively. The skewness and kurtosis are used to determine the normal distribution of variables. The benchmark for skewness is that the value must not be more than 1 . Therefore, looking at oil price and exchange rate, they mirror a normal distribution. Also, the benchmark for kurtosis is that the value must not be greater than 3 to mirror a normal distribution. Premised on the yardstick, both oil price and exchange rate illustrate a normal distribution.

\subsection{Empirical Methods}

The order of integration was determined as an initial test for oil price and exchange rate for Nigeria by utilizing Dickey and Fuller (1981); Phillips and Perron (1988) and Lee and Strazicich (2004) unit root tests. It is well known that before wavelet analysis is carried out, it is essential to carry out unit root tests.

\subsubsection{Wavelet Approaches}

The primary purpose of this paper is to verify the causal interaction between oil price and exchange rate. This is done by deploying the time-frequency domain utilizing the wavelet power spectrum and wavelet coherence techniques. This technique was initiated by Goupillaud, Grossmann, and Morlet (1984). It is generally recognized in economic and finance that non-stationarity remains the prominent feature of time series. According to Pal and Mitra (2017) standalone frequency domain approach main issue is particularly known as Fourier transform, which shows that focusing on frequency domain may lead to complete omission of information. Additionally, estimation of the conventional Granger causality tests will suffer if there is structural break (s) in the variables (Ayobamiji \& Kalmaz, 2020). The wavelet-based Granger causality test is deployed in this paper to refrain from these problems.

The wavelet $(\psi)$ is part of the Morlet wavelet family, Equation 6 depicts the Morlet equation.

$$
\varpi(t)=\pi^{-\frac{1}{4}} e^{-i \varpi t} e^{-\frac{1}{2} t^{2}}
$$

In equation $6, w$ illustrates frequency utilized on the limited time series; $\mathrm{p}(t), n=0,1,2,3 \ldots \ldots \mathrm{N}-1$; and $\sqrt{-1}$ signifies $i$.

Time series are reshaped into the time-frequency domain which links to change in wavelet. $\varpi$ is reshaped; hence, develop into $\varpi_{k, f}$. This is evidence in the Equation 7 below:

$$
\varpi_{k, f}(t)=\frac{1}{\sqrt{h}} \varpi\left(\frac{t-k}{f}\right), k, f \in \mathbb{R}, f \neq 0
$$

In equation 7 , the key variables are $k$ and $f$ which stands for time and place and frequency respectively. Hence, to reveal the link about the time-frequency, continuous wavelet transition (CWT). İs an essential vital factor. Deploying the CWT approach is essential in relating the two time series together. The CWT equation is depicted in the Equation 8 below;

$$
\varpi_{p}(k, f)=\int_{-\infty}^{\infty} p(t) \frac{1}{\sqrt{f}} \varpi\left(\overline{\frac{t-k}{f}}\right) d t,
$$

In Equation 8, p(t) denotes the change in the past time and the coefficient is illustrated by $w$. The Equation 9 below illustrate the summary.

$$
p(t)=\frac{1}{C_{\varpi}} \int_{0}^{\infty}\left[\int_{-\infty}^{\infty}\left|\mathfrak{w}_{p}(a, b)\right|^{2} d a\right] \frac{d b}{b^{2}}
$$

The variance ${ }^{1}$ of the wavelet power spectrum (WPS) of the two time series is illustrated by Equation 10 below;

$$
W P S_{p}(k, f)\left|W_{p}(k, f)\right|^{2}
$$

Kirikkaleli and Ozun (2019) asserted that the cross-spectrum ratio to each spectrum of time-series by combining their frequencies is estimated by the Wavelet Coherence (WTC). The transformation of the time series is represented by the Equation 11 below;.

$$
W_{p q}(k, f)=W_{p}(k, f) \overline{W_{q}(k, f)}
$$

In equation 11 above, the CWT of $\mathrm{p}(\mathrm{t})$ and $\mathrm{q}(\mathrm{t})$ is represented by $W_{f}\left(k_{f} f\right)$ and the value of squared WTC is denoted by $W_{q}\left(k_{f} f\right) \cdot R^{2}(k, f)$. The equation is represented by Equation 12 below;

$$
R^{2}(k, f)=\frac{\left|S\left(f^{-1} W_{p q}(k, f)\right)\right|^{2}}{S\left(f^{-1}\left|W_{p}(k, f)\right|^{2}\right) S\left(f^{-1}\left|W_{q}(k, f)\right|^{2}\right)}
$$

Zero (o) correlation between two series will show if the $R^{2}(k, f)$ are closer to o while correlation will show if $R^{2}(k, f)$ is close to 1 , which spherical thick black line shows and also represented by a warm color (red). Though, $R^{2}(k, f)$ values did not provide information about the sign interaction. Therefore, a procedure that can detect wavelet coherence by deploying differences via deferrals indications in time series wavering is proposed by Torrence and Compo (1998). Wavelet coherence at the difference phase is represented in the Equation 13 below;

$$
\phi_{p q}(k, f)=\tan ^{-1}\left(\frac{\mathrm{L}\left\{S\left(f^{-1} W_{p j}(k, f)\right)\right\}}{o\left\{S\left(f^{-1} W_{p j}(k, f)\right)\right\}}\right)
$$

In Equation 13 above, $\mathrm{L}$ and $\mathrm{O}$ reflect an imaginary operator and a real part operator correspondingly.

\footnotetext{
${ }^{1}$ Variance is denoted as frequency function.
} 


\subsubsection{Causality Tests}

There will be evidence of causality if variables are cointegrated. The direction of this causal effect may be oneway or feedback. Hence, this paper deployed the two conventional causality tests by Granger (1969) and the Toda Yamamoto causality test to ascertain the causality direction between oil price and exchange rate. The Granger causality equation is depicted below in Equations 14 and 15;

$$
\begin{gathered}
O P_{t}=\alpha_{o}+\sum_{i=1}^{t 1} \alpha_{i} O P_{t-1}+\sum_{i=1}^{k 2} \beta_{i} E X C H R_{t-1}+\varepsilon_{t} \\
\text { EXCHR }_{t}=\delta_{o}+\sum_{i=1}^{t 3} \delta_{i} E X C H R_{t-1}+\sum_{i=1}^{k 4} \vartheta_{i} O P_{t-1}+\mu_{t}
\end{gathered}
$$

In Equations 14 and 15, the lag length is represented by $t$, and error terms are depicted by $\varepsilon_{t}$ and $\mu$ respectively. It is easy to execute the Granger causality test, however, their several drawbacks are attached to it. These drawbacks are; (i) specification biased by not considering another variable; (ii) lag selection bias; (iii) most time series variables are not stationary (Maddala, Li, \& Srivastava, 2001) which may lead to baseless estimate; and (iv) unreliability of the F-statistics method, thus making it difficult to depend on the outcome of the Granger causality test (Gujarati, 2006).

Toda and Phillips (1994) identify some drawbacks in the Granger causality test. Toda and Yamamoto (1995) generated a new procedure that solves most drawbacks linked to the Granger causality test. This involves adding the augmented VAR estimate that ensures the distribution asymptotic of the Wald statistics (asymptotic $\chi^{2}$ distribution) as a robustness check method to the system integration and properties of cointegration. Equations 16 and 17 illustrates the Toda Yamamoto causality test;

$O P_{t}=\delta_{o}+\sum_{i=1}^{m} \vartheta_{i} O P_{t-1}+\sum_{i=m+1}^{m+d m a x} \vartheta_{i} O P_{t-1}+\sum_{i=1}^{m} \beta_{1} E X C H R_{t-1}+\sum_{i=m+1}^{m+d m a x} \beta_{1} E X C H R_{t-1}+\mu_{t}$

$$
\begin{aligned}
\operatorname{EXCHR}_{t}=\omega_{o} & +\sum_{i=1}^{m} \alpha_{i} E X C H R_{t-1}+\sum_{\substack{i=m+1 \\
m+d m a x}}^{m E X C H R_{t-1}} \\
& +\sum_{i=1}^{m} \pi_{1} O P_{t-1}+\sum_{i=m+1}^{m+d \max } \pi_{1} O P_{t-1}+\mu_{t}
\end{aligned}
$$

In Equations 16 and 17 , OP denotes oil price, EXCHR illustrate the exchange rate, dmax is the maximum integration order that the system is assumed to have, $\mu_{t}$ and $\varepsilon_{t}$ are error terms and AIC, SC, FPE, and HQ are measures deployed to ascertain the lag selection of the VAR.

\section{Discourse of Findings}

\subsection{Unit Root Test}

Unit root tests are applied to oil price and exchange rates to examine integration order by deploying ADF and $\mathrm{PP}$ unit root tests. In Panel $\mathrm{B}$ in Table 2, when executing the tests, the variables are presumed not to have a structural break (s). However, when structural break (s) is taken into consideration, the Zivot-Andrews (ZA) unit

\begin{tabular}{|c|c|c|c|c|}
\hline \multicolumn{5}{|c|}{ Panel B: Unit Root Without Structural Break (s) } \\
\hline Variables & $\mathrm{ADF}(\mathrm{K} \& \mathrm{~T})$ & Decision & $\mathbf{P P}(\mathrm{K} \& \mathrm{~T})$ & Decision \\
\hline OP & $-7.678^{*}$ & $\mathrm{I}(1)^{*}$ & $-7.691 *$ & $\mathrm{I}(1)^{*}$ \\
\hline EXCHR & $-8.933^{*}$ & $\mathrm{I}(1)^{*}$ & $-9.070^{*}$ & $\mathrm{I}(1)^{*}$ \\
\hline \multicolumn{5}{|c|}{ Panel A: Unit Root with Structural Break (s) } \\
\hline & $\mathrm{ZA}(\mathrm{K} \& \mathrm{~T})$ & Decision & LM & Decision \\
\hline $\mathrm{OP}$ & $\begin{array}{c}-8.08^{*} \\
{[2 \mathrm{O} 18 \mathrm{M} 2]}\end{array}$ & $\mathrm{I}(1)^{*}$ & $\begin{array}{c}-6.122^{*} \\
{[2 \mathrm{O} 08 \mathrm{M} 11]\{2018 \mathrm{M} 9\}}\end{array}$ & $\mathrm{I}(1)^{*}$ \\
\hline EXCHR & $\begin{array}{c}-10.094^{*} \\
{[2 \mathrm{O} 17 \mathrm{M} 2]}\end{array}$ & $\mathrm{I}(1)^{*}$ & $\begin{array}{c}-6.196^{*} \\
{[2 \mathrm{O} 9 \mathrm{M} 1]\{2016 \mathrm{M} 1\}}\end{array}$ & $\mathrm{I}(1)^{*}$ \\
\hline
\end{tabular}
root test and Lee \& Strazicich (LM) unit root test which can detect one structural break and two structural breaks respectively were used.

Table-2. Unit Root.

\subsection{Wavelet Power Spectrum Result}

The study deployed the wavelet power spectral test to detect the behavior and vulnerability of the oil price and exchange rate. The wavelet power spectral for oil price and exchange rate is illustrated by Figure $3 \& 4$ portraying an edge below where the wavelet power is impacted because of discontinuity, whereas the Monte Carlo simulations is deployed to determine the $5 \%$ significance level as indicated by the black thick shape. 


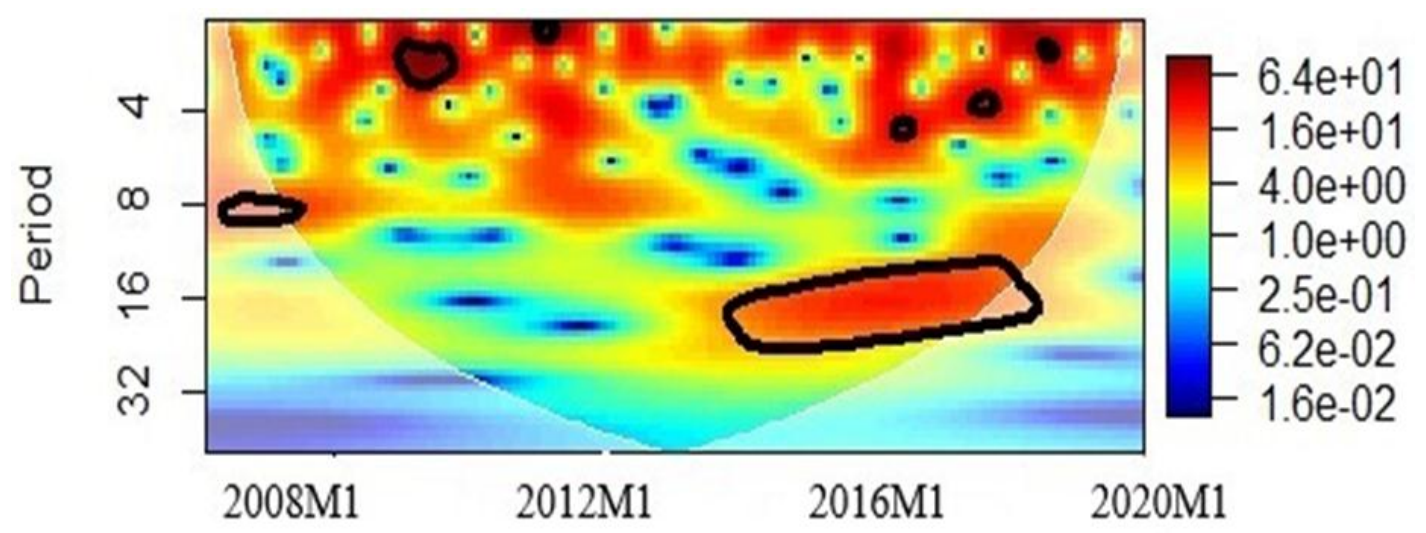

Time

Figure-3. WPS for exchange rate.

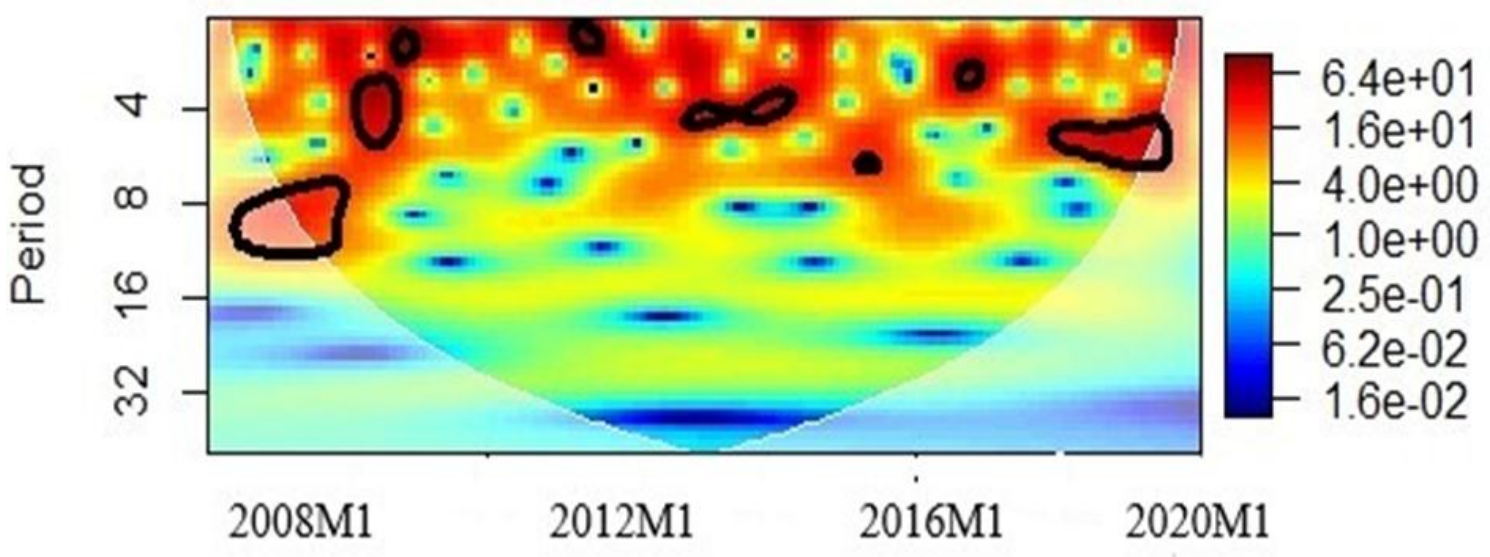

Time

Figure-4. WPS for oil price.

Figure 4 portrays the wavelet power spectrum of exchange rate between 2007M1 and 2020M3. At scale 16-32, there is a significant vulnerability in exchange rate in Nigeria between 2014M6 and 2014M12. This is due to fall in oil price by over $50 \%$ from $\$$ US115 in June 2014 to $\$$ US50 per barrel which brought a fall in exchange rate. Between 2016M1 and 2016M4 which represent the first quarter, at scale 8-16 there is sign of significant vulnerability in the exchange rate. In this period, Nigeria pegged it currency against the US dollars due to high inflation in the country. There is high vulnerability in exchanger rate at scale 16-32 between $2017 \mathrm{M} 1$ and 2017M12. This is as a result of collapsing oil price which heaped pressure on the naira. Figure 4 illustrates the wavelet power spectrum of oil price between $20007 \mathrm{M} 1$ and 2020M3. At scale 8-16 between 2008M1 and 2008M12, a significant vulnerability in oil price surfaced. This is due to series of events that limit global production oil which lead to a significant spike in oil prices. For instance, Venezuela cut off sales to Exxon Mobil in a massive battle over nationalization. Export from Iran and Iraq had not recovered, the decline in Mexico oil field and labour strike reduced production in Nigeria. In the second half of 2008 , recession and financial crises caused oil price to drop to $\$ 50$ per barrel. At scale $4-8$, between $2014 \mathrm{M} 1$ and $2014 \mathrm{M} 12$, a significant vulnerability in oil price surfaced. This is due to a decrease in oil demand by emerging economies such as China and India which caused decrease in the oil price.

\subsection{Wavelet Coherence Result}

To explore the co-movement and causality between exchange rate and oil price in Nigeria, this study deployed the wavelet approach. The $\mathrm{x}$-axis and $\mathrm{y}$-axis portray the time and frequency separately. The grey cone-shaped line in Figure 3 mirrors the cone of impact whereas the thick black contour reflects the significance level of $5 \%$ against the AR(1). The cold (blue) and warmer red (hot) color signifies the zero dependency and high dependency respectively in Figure 3. Rightward and leftward arrows illustrate positive and negative co-movement respectively between the two-time series respectively. Furthermore, when arrows point rightward and up or leftward and down it shows that the second variable causes the first variable and when the arrows are leftward and up or rightward and down it shows that the first variable causes the second variable. 


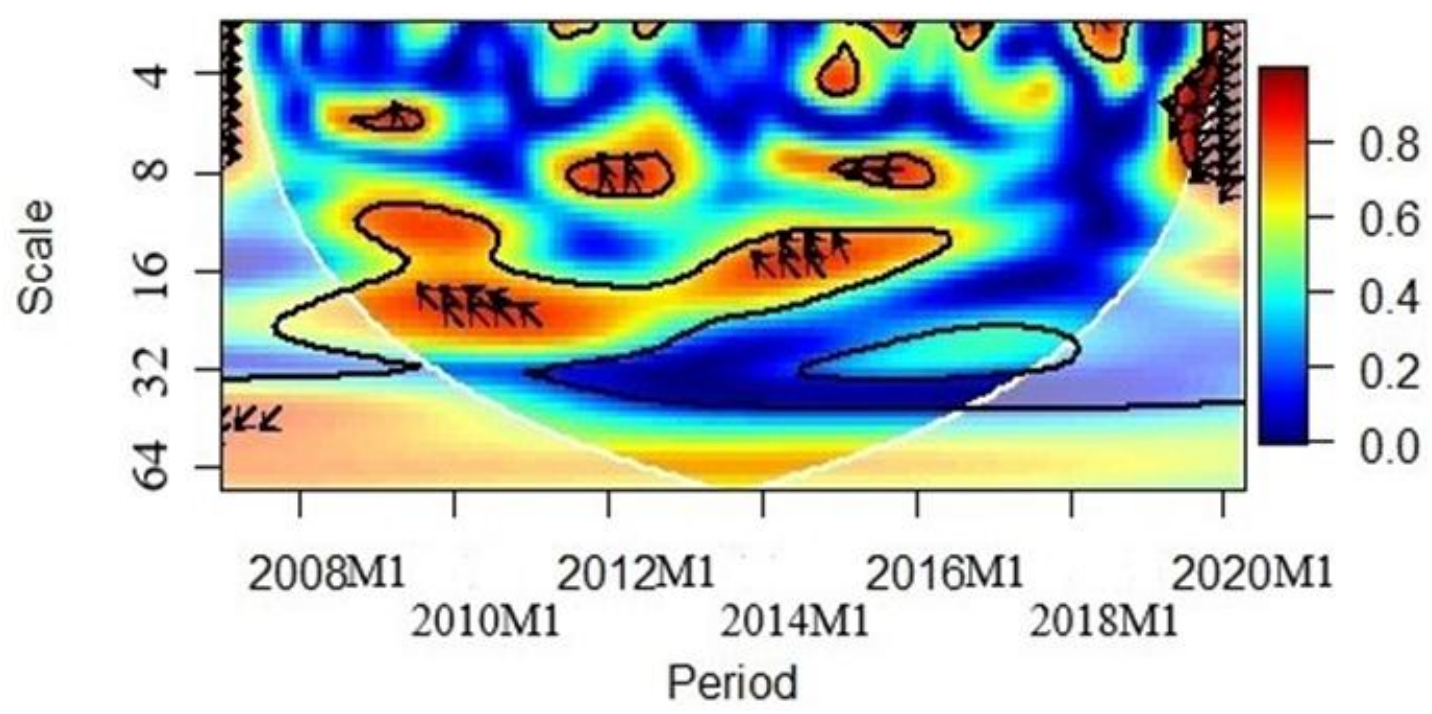

Figure-5. Wavelet Coherence: Exchange rate vs oil price.

Figure 5 portrays the wavelet coherence between exchange rate and oil price between January 2007 and March 2020. The leftward arrow between $2009 \mathrm{M} 10$ and $2011 \mathrm{M} 3$, between $2012 \mathrm{M} 1$ and $2012 \mathrm{M} 3$, between $2014 \mathrm{M} 2$, 2015M6 and between 2019M2 and 2019M11 shows a negative correlation between exchange rate and oil price. The negative co-movement corresponds with the outcomes of Turhan et al. (2014) and Yang et al. (2017). Furthermore, leftward and up arrows at the thick black contour between $2009 \mathrm{M} 10$ and $2011 \mathrm{M} 3$, between $2012 \mathrm{M} 1$ and $2012 \mathrm{M} 3$, between $2014 \mathrm{M} 2$ and $2015 \mathrm{M} 6$ depicts that exchange rate cause oil price while leftward and down arrows between $2019 \mathrm{M} 2$ and 2019M11 signifies that oil price cause exchange rate.

\subsection{Causality Tests}

Table-3. Causality tests.

\begin{tabular}{l|l|l|l|l}
\hline & Direction of Causality & Lag(s) & F-Stat(Prob) & Decision \\
\hline \multirow{2}{*}{ Granger Causality } & EXCHR $\rightarrow$ Oil & 2 & $\{3.612\}^{* *}$ & ${\text { Reject } \mathrm{H}_{\mathrm{O}}}$ \\
\cline { 2 - 5 } & Oil $\rightarrow$ EXHR & 2 & $\{6.601\}^{*}$ & Reject $\mathrm{H}_{\mathrm{O}}$ \\
\hline \multirow{2}{*}{ Toda Yamamoto } & & & & \\
& Direction of Causality & $\mathrm{Lag}(\mathrm{s})$ & MWALD (Prob) & Decision \\
\cline { 2 - 5 } & EXCHR $\rightarrow$ Oil & 2 & $\{10.572\}^{*}$ & Reject $\mathrm{H}_{\mathrm{O}}$ \\
\cline { 2 - 5 } & Oil $\rightarrow$ EXHR & 2 & $\{21.054\}^{*}$ & Reject $\mathrm{H}_{\mathrm{O}}$ \\
\hline Note: $\rightarrow$ stands for direction of the direction of causality **** and **** mirror significance at $1 \%$ \& $5 \%$ levels, correspondingly
\end{tabular}

Optimal lag for the model has been selected using SC information criteria $(\mathrm{Lag}=2)$ modified Wald test statistic.

Table 3 denotes the causality tests carried out. For robustness check for the wavelet coherence approach result, the Granger and Toda-Yamamoto causality techniques were deployed to explore the causality between oil price and exchange rate in Nigeria. Findings from both causality tests revealed there is support for feedback causality between oil price and exchange rate. This finding is supported by previous studies on oil price and exchange rate interaction (Cifarelli \& Paladino, 2010; Huang et al., 2020; Turhan et al., 2014; Yang et al., 2017).

\subsection{Variance Decomposition Result}

The Granger and Toda Yamamoto causality tests cannot predict the relative power of causality for time series beyond the study time. Therefore, due to this loophole, the variance decomposition is deployed to investigate the causality strength between the time series variables 24 months ahead and to ascertain causality efficacy.

To ascertain the exact impact of oil price on exchange rate and the influence of exchange rate on oil price for 24 months, the variance decomposition analysis is deployed. From the first month to the fifth month, nearly all the discrepancies in oil price can be explained by itself. However, in the twenty-third and twenty-fourth month which are in the long term, the exchange rate can predict $14.08 \%$ and $15 \%$ of the discrepancy in oil price. For exchange rate, in the first and second months, exchange rate can predict $99 \%$ and $95 \%$ of the variation of itself. However, as the months dwindle, $40.2 \%$ and $40.5 \%$ of discrepancy in exchange rate can be expressed by oil price in the twentythird and twenty-fourth month respectively. This signifies that oil price is a good predictor of the exchange rate in the long term.

\section{Conclusion and Recommendations}

This paper explores the connection between the exchange rate and price of oil within the framework of time and frequency utilizing monthly data between January 2007 and March 2020. The study deployed the wavelet power spectrum and wavelet coherence techniques to investigate this relationship. Furthermore, Granger and Toda Yamamoto causality tests were deployed as a robustness check for the wavelet coherence techniques. Findings from the wavelet power spectrum shows; (a) there is a vulnerability in exchange rate between 2014M6 and $2014 \mathrm{M} 12$, between $2017 \mathrm{M} 1$ and $2017 \mathrm{M} 12$; and (b) there is a high vulnerability in oil price between $2008 \mathrm{M} 1$ and $2008 \mathrm{M} 12$, between $2014 \mathrm{M} 1$ and $2014 \mathrm{M} 12$. The wavelet coherence technique reveals; (a) negative comovement between the exchange rate and oil price between 2009M10 and 2011M3, between 2012M1 and 2012M3, between $2014 \mathrm{M} 2,2015 \mathrm{M} 6$ and between $2019 \mathrm{M} 2$ and 2019M11. Also, the adverse interaction between the price of oil and the exchange rates for Nigeria which is an oil-exporting nation is confirmed. This finding aligns with the study of Yang et al. (2017) on the influence of oil price shock on exchange rate. 
Table-4. Variance decomposition.

\begin{tabular}{|c|c|c|c|}
\hline \multicolumn{4}{|c|}{ Decomposition of Oil Price } \\
\hline Months & S.E. & OP & EXCHR \\
\hline 1 & 0.039733 & 100.0000 & 0.000000 \\
\hline 2 & 0.065521 & 98.07864 & 1.921363 \\
\hline 3 & 0.086260 & 96.17240 & 3.827603 \\
\hline 4 & 0.102671 & 94.67534 & 5.324659 \\
\hline 5 & 0.115557 & 93.50412 & 6.495879 \\
\hline 6 & 0.125675 & 92.55896 & 7.441042 \\
\hline 7 & 0.133662 & 91.76945 & 8.230547 \\
\hline 8 & 0.140019 & 91.08946 & 8.910538 \\
\hline 9 & 0.145135 & 90.48884 & 9.511165 \\
\hline 10 & 0.149302 & 89.94756 & 10.05244 \\
\hline 11 & 0.152739 & 89.45203 & 10.54797 \\
\hline 12 & 0.155613 & 88.99279 & 11.00721 \\
\hline 13 & 0.158049 & 88.56306 & 11.43694 \\
\hline 14 & 0.160141 & 88.15786 & 11.84214 \\
\hline 15 & 0.161961 & 87.77343 & 12.22657 \\
\hline 16 & 0.163566 & 87.40690 & 12.59310 \\
\hline 17 & 0.164996 & 87.05597 & 12.94403 \\
\hline 18 & 0.166287 & 86.71882 & 13.28118 \\
\hline 19 & 0.167462 & 86.39395 & 13.60605 \\
\hline 20 & 0.168544 & 86.08014 & 13.91986 \\
\hline 21 & 0.169548 & 85.77635 & 14.22365 \\
\hline 22 & 0.170487 & 85.48172 & 14.51828 \\
\hline 23 & 0.171371 & 85.19549 & 14.80451 \\
\hline 24 & 0.172209 & 84.91705 & 15.08295 \\
\hline \multicolumn{4}{|c|}{ Decomposition of Exchange Rate } \\
\hline Months & S.E. & $\mathbf{O P}$ & EXCHR \\
\hline 1 & 0.014842 & 0.005003 & 99.99500 \\
\hline 2 & 0.023811 & 4.721360 & 95.27864 \\
\hline 3 & 0.031982 & 10.37145 & 89.62855 \\
\hline 4 & 0.039621 & 15.24506 & 84.75494 \\
\hline 5 & 0.046791 & 19.20619 & 80.79381 \\
\hline 6 & 0.053539 & 22.41656 & 77.58344 \\
\hline 7 & 0.059909 & 25.04930 & 74.95070 \\
\hline 8 & 0.065944 & 27.24032 & 72.75968 \\
\hline 9 & 0.071678 & 29.08945 & 70.91055 \\
\hline 10 & 0.077144 & 30.66938 & 69.33062 \\
\hline 11 & 0.082367 & 32.03363 & 67.96637 \\
\hline 12 & 0.087370 & 33.22227 & 66.77773 \\
\hline 13 & 0.092172 & 34.26587 & 65.73413 \\
\hline 14 & 0.096789 & 35.18819 & 64.81181 \\
\hline 15 & 0.101236 & 36.00802 & 63.99198 \\
\hline 16 & 0.105524 & 36.74046 & 63.25954 \\
\hline 17 & 0.109665 & 37.39778 & 62.60222 \\
\hline 18 & 0.113669 & 37.99009 & 62.00991 \\
\hline 19 & 0.117544 & 38.52582 & 61.47418 \\
\hline 20 & 0.121298 & 39.01203 & 60.98797 \\
\hline 21 & 0.124939 & 39.45469 & 60.54531 \\
\hline 22 & 0.128473 & 39.85891 & 60.14109 \\
\hline 23 & 0.131907 & 40.22905 & 59.77095 \\
\hline 24 & 0.135245 & 40.56887 & 59.43113 \\
\hline
\end{tabular}

The Granger and Toda Yamamoto causality tests reveal a bidirectional interaction between oil price and exchange rate. The variance decomposition shows that as the months dwindle, $40.2 \%$ and $40.5 \%$ of discrepancy in exchange rate can be explained by oil price in the twenty-third and twenty-fourth month respectively. This signifies that oil price is a good predictor of the exchange rate in the long term. Both the variance decomposition and causality tests provide supportive evidence for the wavelet coherence technique. Findings from this paper propose interesting suggestions for policymakers and investors. Concerning investors, oil price and exchange rate connection are unstable in the short run, though there is evidence of stability in the medium term. Also, the investors must implement hedge strategies since the exchange rates are responsive to shifts in oil price in Nigeria. In regards to policymakers, oil price is a vital determinant of exchange rate which is due to Nigeria over-reliance on oil sales in generating revenue. Therefore, Nigeria should diversify its economy since the exchange rate is sensitive to oil price.

\section{References}

Adeniyi, O. A., Omisakin, D., Olusegun, A., Yaqub, J., \& Oyinlola, A. (2012). Oil price-exchange rate nexus in Nigeria: Further evidence from an oil exporting economy. International Journal of Humanities and Social Science, 13(8), 576-593.

Aliyu, S. U. R. (2009). Impact of oil price shock and exchange rate volatility on economic growth in Nigeria: An empirical investigation. Published in: Research Journal of International Studies, $11(5), 4-15$.

Amano, R. A., \& Van Norden, S. (1998). Oil prices and the rise and fall of the US real exchange rate. Journal of international Money and finance, 17(2), 299-3 16.Available at: https://doi.org/10.1016/s0261-5606(98)00004-7.

Ayobamiji, A. A., \& Kalmaz, D. B. (2020). Reinvestigating the determinants of environmental degradation in Nigeria. International Journal of Economic Policy in Emerging Economies, 13(1), 52-71.Available at: https://doi.org/10.1504/ijepee.2020.106680. 
Baek, J., \& Kim, H.-Y. (2020). On the relation between crude oil prices and exchange rates in sub-saharan African countries: A nonlinear ARDL approach. The Journal of International Trade \& Economic Development, 29(1), 119-130.

Basnet, H. C., \& Upadhyaya, K. P. (2015). Impact of oil price shocks on output, inflation and the real exchange rate: Evidence from selected ASEAN countries. Applied Economics, 47(29), 3078-3091.Available at: https://doi.org/10.1080/00036846.2015.1011322.

Camarero, M., \& Tamarit, C. (2002). Oil prices and Spanish competitiveness: A cointegrated panel analysis. Journal of Policy Modeling, 24(6), 591-605.Available at: https://doi.org/10.1016/s0161-8938(02)00128-x.

Central Bank of Nigeria. (2020). Retrieved from www.cbn.gov.ng [Accessed on 2 March 2020].

Chen, S. S., \& Chen, H. C. (2007). Oil prices and real exchange rates. Energy Economics, 29(3), 390-404.

Cifarelli, G., \& Paladino, G. (2010). Oil price dynamics and speculation: A multivariate financial approach. Energy Economics, 32(2), 363372.Available at: https://doi.org/10.2139/ssrn.1295353.

Dickey, D. A., \& Fuller, W. A. (1981). Likelihood ratio statistics for autoregressive time series with a unit root. Econometrica: journal of the Econometric Society, 49(4), 1057-1072.Available at: https://doi.org/10.2307/1912517.

Ghosh, S. (2011). Examining crude oil price-Exchange rate nexus for India during the period of extreme oil price volatility. Applied Energy, 88(5), 1886-1889.Available at: https://doi.org/10.1016/j.apenergy.2010.10.043.

Golub, S. S. (1983). Oil prices and exchange rates. The Economic Journal, 93(371), 576-593.

Goupillaud, P., Grossmann, A., \& Morlet, J. (1984). Cycle-octave and related transforms in seismic signal analysis. Geoexploration, 23(1), 85102.

Granger, C. (1969). Investigating causal relations by econometric models and cross-spectral. Econometrica, 37(3), 424-438.Available at: https://doi.org/10.2307/1912791.

Gujarati, D. N. (2006). Essential of econometrics (3rd ed.). New York: McGraw-Hill.

Huang, S., An, H., \& Lucey, B. (2020). How do dynamic responses of exchange rates to oil price shocks co-move? From a time-varying perspective. Energy Economics, $10(5), 32-41$.

Iwayemi, A., \& Fowowe, B. (2011). Impact of oil price shocks on selected macroeconomic variables in Nigeria. Energy Policy, 39(2), 603612.Available at: https://doi.org/10.1016/j.enpol.2010.10.033.

Kirikkaleli, D., \& Ozun, A. (2019). Innovation capacity, business sophistication and macroeconomic stability: Empirical evidence from OECD countries. Journal of Business Economics and Management, 20(2), 351-367.Available at: https://doi.org/10.3846/jbem.2019.9602.

Korhonen, I., \& Juurikkala, T. (2009). Equilibrium exchange rates in oil-exporting countries. Journal of Economics and Finance, 33(1), 7179.Available at: https://doi.org/10.1007/s12197-008-9067-x.

Krugman, P. (1983). New theories of trade among industrial countries. The American Economic Review, 73(2), 343-347.

Lee, J., \& Strazicich, M. C. (2004). Minimum LM unit root test with one structural break. Manuscript, Department of Economics, Appalachian State University, 37(5), 1-16.

Lizardo, R. A., \& Mollick, A. V. (2010). Oil price fluctuations and US dollar exchange rates. Energy Economics, 32(2), 399-408.Available at: https://doi.org/10.1016/j.eneco.2009.10.005.

Maddala, G., Li, H., \& Srivastava, V. K. (2001). A comparative study of different shrinkage estimators for panel data models. Annals of Economics and Finance, 2(1), 1-30.

Olayungbo, D. (2019). Effects of global oil price on exchange rate, trade balance, and reserves in nigeria: a frequency domain causality approach. Journal of Risk and Financial Management, 12(1), 1-14.Available at: https://doi.org/10.3390/jrfm 12010043.

Pal, D., \& Mitra, S. K. (2017). Time-frequency contained co-movement of crude oil and world food prices: A wavelet-based analysis. Energy Economics, 62, 230-239.Available at: https://doi.org/10.1016/j.eneco.2016.12.020.

Phillips, P. C., \& Perron, P. (1988). Testing for a unit root in time series regression. Biometrika, 75(2), 335-346.Available at: https://doi.org/10.1111/jtsa.12279.

Reboredo, J. C., \& Rivera-Castro, M. A. (2013). A wavelet decomposition approach to crude oil price and exchange rate dependence. Economic Modelling, 32(5), 42-57.Available at: https://doi.org/10.1016/j.econmod.2012.12.028.

Toda, H. Y., \& Phillips, P. C. (1994). Vector autoregression and causality: A theoretical overview and simulation study. Econometric Reviews, 13(2), 259-285.Available at: https://doi.org/10.1080/07474939408800286.

Toda, H. Y., \& Yamamoto, T. (1995). Statistical inference in vector autoregressions with possibly integrated processes. Journal of Econometrics, 66(1-2), 225-250.Available at: https://doi.org/10.1016/0304-4076(94)01616-8.

Torrence, C., \& Compo, G. P. (1998). A practical guide to wavelet analysis. Bulletin of the American Meteorological society, 79(1), 61-78.

Turhan, M. I., Sensoy, A., \& Hacihasanoglu, E. (2014). A comparative analysis of the dynamic relationship between oil prices and exchange rates. Journal of International Financial Markets, Institutions and Money, 32(6), 397-414.

Yang, L., Cai, X. J., \& Hamori, S. (2017). Does the crude oil price influence the exchange rates of oil-importing and oil-exporting countries differently? A wavelet coherence analysis. International Review of Economics \& Finance, 49(14), 536-547.

Yang, L., Yang, L., Ho, K. C., \& Hamori, S. (2019). Determinants of the long-term correlation between crude oil and stock markets. Energies, 12(21), 23-41.Available at: https://doi.org/10.3390/en 12214123.

Zalduendo, J. (2006). Determinants of Venezuela's equilibrium real exchange rate. Working Paper No. O6/74.International Monetary Fund, Washington DC. 